\title{
Tetrandrine Suppresses Transient Receptor Potential Cation Channel Protein 6 Overexpression- Induced Podocyte Damage via Blockage of RhoA/ROCKI Signaling [Corrigendum]
}

\author{
Yu J, Zhu C, Yin J, et al. Drug Des Dev Ther. The authors apologize for this error.
} 2020;14:361-370.

The authors have advised that in Figure 3 on page 365, the image of the Blank group was mistakenly duplicated from the NC group. The correct figure is below.

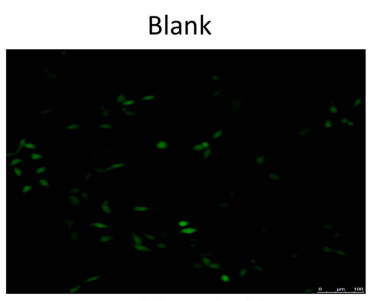

TRPC6+U73122

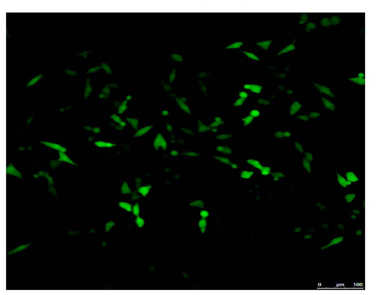

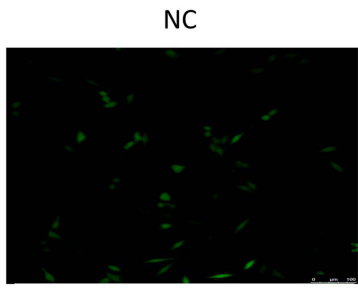

TRPC6+Valsartan

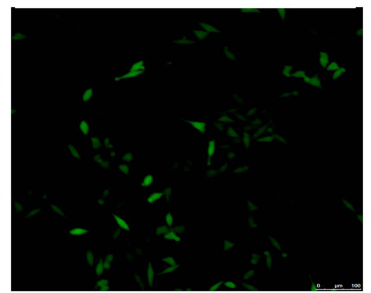

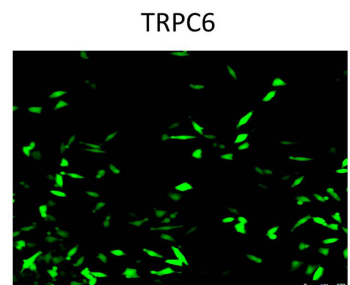

TRPC6+Tetrandrine

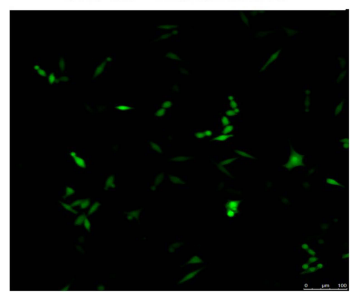

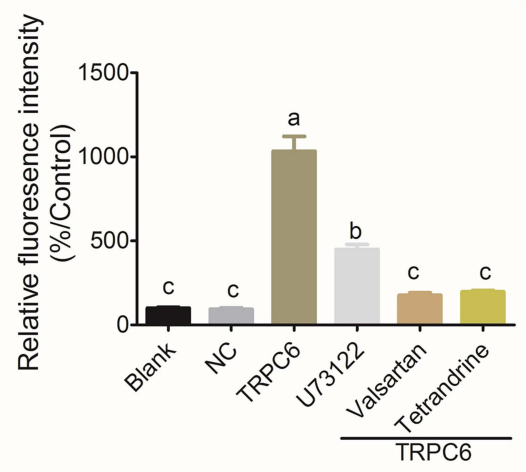

Figure 3 Tetrandrine inhibits TRPC6 overexpression-induced intracellular $\mathrm{Ca}^{2+}$ influx in MPC5 podocytes. Fluorescence image of fluo-3AM loaded cells (green) indicates intracellular $\mathrm{Ca}^{2+}$ influx. Differences were analyzed using one-way ANOVA. Significant differences with $\mathrm{p}<0.05$ are indicated by different letters. NC: containing blank lentivirus vector. blank:normal MPC5 podocyte. TRPC6 group: TRPC6-overexpressing.

\section{Publish your work in this journal}

Drug Design, Development and Therapy is an international, peerreviewed open-access journal that spans the spectrum of drug design and development through to clinical applications. Clinical outcomes, patient safety, and programs for the development and effective, safe, and sustained use of medicines are a feature of the journal, which has also been accepted for indexing on PubMed Central. The manuscript management system is completely online and includes a very quick and fair peer-review system, which is all easy to use. Visit http://www. dovepress.com/testimonials.php to read real quotes from published authors. 